\author{
Slobodan LJ. Pavlović* \\ University of Kragujevac, Faculty of Education in Užice \\ Dragan B. Marinković ${ }^{*}$ \\ University of Novi Sad, Faculty of Sport and Physical Education
}

Nebojša Z. Mitrović*

University of Bijeljina, Faculty of Education

\title{
MOTOR SKILLS OF PRIMARY SCHOOL CHILDREN - THE DIFFERENCES COMPARED TO AGE
}

\begin{abstract}
Physical education, from the earliest age in preschool institutions, and then through primary and secondary schools, is the only place where children can, in the right way, acquire the knowledge on sports, skills, behaviour, necessary in order to get the continuity of physical activities in the adulthood. Primary school is a period when the students experience great changes in the overall developing status. Therefore, Physical Education has a fundamental role in the development of psychosomatic characteristics of children. While planning lessons of Physical Education, there is a special emphasis on the development of motor skills. The goal of this research refers to the establishing of the existing differences in the motor space of primary school children in relation to age. The sample consisted of 231 examinees who attended 3rd, 4th, 5th and 6th grade (age $11 \pm 1.6$ years), out of which there were $(\mathrm{N}=109$; $\mathrm{TV}=147.6 \pm 7$; $\mathrm{TM}=39.6 \pm 7.1)$ boys, and $(\mathrm{N}=122 ; \mathrm{TV}=148.3 \pm 5.9 ; \mathrm{TM}=40 \pm 5.3)$ girls. All examinees were the students from the territory of Zlatibor region and with the signed permission for performing testing by both parents. Motor skills have been estimated within school Physical Education, all with the purpose of getting more realistic picture on the motor skills of children. The presented results point to the existing differences between the groups of examinees of both genders on a general level, as well as the individual differences within the motor space. These differences are more noticable with boys $(\mathrm{F}=5.92 ; \mathrm{P}=.00)$ than with girls $(\mathrm{F}=$ 4.79; $\mathrm{P}=.00)$. Statistically greater differences with boys have been noted in the following variables: "Hand tapping", "Hand claping", "Throwing basketball ball", "The $30 \mathrm{~m}$ running flying start", "Pull-ups", and "Torso lift-ups". With girls, statistically significant difference have been notes in the following variables: „Throwing basketball ball”, „The $30 \mathrm{~m}$ running flying start” and "Torso lift-ups". The value of this work is reflected in the fact that, during testing,
\end{abstract}

\footnotetext{
*slobodan.b.pavlovic@gmail.com

*marinkovicdragan@ @otmail.com

*nebojsa.mitrovic@pfb.ues.rs.ba
} 
a great number of tests were used for estimation of the examinees' motor space, all with the purpose of getting more complete picture on the existance of differences among the groups, categorised by gender and age. The importance of testing and perception of differences in motor skills and their monitoring presents one of the important activities during PE classes, all with the purpose of the adequate lesson programming, but also monitoring the motor development.

Keywords: motor development, Physical Education (PE), motor space, monitoring.

\section{INTRODUCTION}

Physical education is a process used in order to: find out the terms, laws, truths, rules, standards on health and body movement, exercising; acquire, improve and strengthen skills, techniques and styles of body movement, exercising; arouse and stimulate specific affinities and needs (habits and rules); maintain and improve elementary and complex psychophysical abilities and create the attitude about the world with specific opinions and convictions on health and body movement exercising. Physical Education, like education in general, is not and must not be different by the structure of elements which make it as a process, but only with the specific emphasis of some elements of that structure and the uniqueness of the process results (Matić, 1978).

Primary school is a period when the students experience great changes in the overall developing status, therefore Physical Education has a fundamental role in the development of all psychosomatic characteristics of children (Horvat \& Vuleta, 2002). While planning lessons of Physical Education, there is a special emphasis on the development of motor skills (Katić, Miletić, Maleš, Grgantov, Krstulović, 2005). The level of motor skills development with children of younger school age determines their proper physiological growth and development. Throughout the period of younger school age (from the age of seven till the age of eleven), classes which sistematically affect the development of motor space have the greatest result, and biological maturity significantly influences the motor performance (Malina, Koziel, Bielicki, 1999). Developing, evaluating, permanent monitoring and estimation of motor skills of children is an important task of the teaching process. In order for development of motor skills to run progressively, some energetic and psychological conditions must be met, such as coordination, strength, stamina and flexibility (Drabik, 1996).

In principle, boys have better results on tests of explosive strength and coordination and girls achieve better results in testing of repetitive strength, flexibility and balance (Privitellio, Jogunica, Gulan, Bosch, 2007). Beter motor skills with boys come from more intensive movement in preschool as well as in younger school age (Sabolc \& Lepes, 2012). Mutual expression of motor skills implies for one motor skill to be compensated with the other. Accordingly the child 
expresses its complex motor skill in different situations and tasks (Nićin, 2000). The level of motor skills directly affects the growth and development of child (Buišić, Cvejić, Vuković, Živković, Pejović, 2013). Whether they become exceptional sportsmen or not, our motor skills transform year after year, and in order to understand those transformations in a better way, it is necessary to continuously monitor and study the motor skills (Metcalfe \& Clark, 2002).

According to the above mentioned researches, the objective of this research was set and it refers to establishing the existing differences in motor space of primary school children in relation to age and gender.

\section{METHOD}

The sample consists of 231 examinees who attended: third, fourth, fifth and sixth grade (age $11 \pm 1.6$ years), out of which $(\mathrm{N}=109 ; \mathrm{TV}=147.6 \pm 7 ; \mathrm{TM}=39.6$ $\pm 7.1)$ boys and $(\mathrm{N}=122$; $\mathrm{TV}=148.3 \pm 5.9 ; \mathrm{TM}=40 \pm 5.3)$ girls. All examinees were the students from the territory of Zlatibor region and with the signed permission by both parents for testing. The testing has been performed according to the instructions and with respect to Helsinki declaration. The sample of examinees is determined by random selection (randomization), all for the purpose of achieving a relevant reasearch.

Motor skills have been estimated with the following motor tests, in order to establish the overall motor space of the examinees. The tests that were applied:

Hand tapping (number of repeats):

The examinee is sitting on a chair at a table on which there is a board for tapping. Left hand palm is placed in the middle of the board and the right hand is crossed over the left, with the palm placed on the left panel on the board (lefthanded just do the opposite). At the signal "now", within 15 seconds, with his/her right hand fingers, the examinee touches alternately right and then left panel of the tapping board as fast as he/she can. The result of the test is the number of regularly performed alterante finger taps of the examinees within 15 seconds, where tappings both in one and the other panel represent one cycle.

\section{Leg tapping (number of repeats):}

The examinee is sitting on the front part of the chair, not leaning his/her back on backrest, while the hands are placed on the waist. Tapping board consists of two rectangular boards fastened one to another so they form the shape of the inverted letter "T". It is placed in front of the chair so that it pushes its longer side against the right leg of the chair. The opposite narrow side is fixed by foot of the person who measures everything. The examinee sets the leg on the ground by the vertiacl board which works as a barrier, and the right leg on the board which works as a base, on 
the left of barrier (for left-handed, the other way round). At the signal "now", within 15 seconds, the examinee transfers the right leg from one side of the barrier to the other as fast as he/she can, touching, with the front part of the foot or with the whole foot, a horisontal side of the base. The result of the test is the number of the alternate regular leg tapping against the board within 15 seconds.

\section{Hands clapping (number of repeats):}

The examinee is standing, with clenched hands in front of the body with palms and fingers touching. At the signal „now”, the examinee is alternately clapping in front of and behind the body. The task is performed within 15 seconds. One cycle represents the clapping performed in front of and behind the body. The result of the test is the number of regularly performed and completed cycles within the set time.

\section{Backward polygon (s):}

The gym with flat and smooth floor of minimal dimensions of $12 \times 3 \mathrm{~m}$. The upholstered part of vaulting box is placed on the ground, $3 \mathrm{~m}$ away from the starting line, then the first frame of vaulting box is placed $6 \mathrm{~m}$ away from the starting line. Both obstacles are set transversely on the track. From the second obstacle to the finishing line, the distance is $3 \mathrm{~m}$. The examinee is standing on all fours behind the starting line, turning his/her back towards the obstacles. At the signal "now", walking backwards on all fours, the examinee crosses the first obstacle, goes through the second and contiunes in the same position until he/she crosses the finishing line. During the test, the examinee must not turn his/her head. The result of the test is the time of performing the described motor task, expressed in hundredths of a second.

\section{Bat coordination test (s):}

The examinee is standing faced towards the narrow part of the exercise mat, holding $1 \mathrm{~m}$ long mat behing his/her back in overgrip for both ends. At the signal "now", overstepping the bat, first with one leg and then with the other, until the bat comes in the position in front of the body, turning in $180^{\circ}$ degrees, sits, immediately lying down on the back, holding the bat on the face, continuously, with both hands, then pulling the leg through and then pulling first one and then the other leg, lifting up, placing the bat now on the back, crossing it first with one leg and then the other, bringing it in front of the body, up to the height of shoulders. The result of the test is the time of performance of the described motor task, expressed in hundredths of a second.

Pulling through and jumping over (s):

There are four paralelly set frames of vaulting box on the ground, at a distance of $1.5 \mathrm{~m}$. In front of the first and behind the last frame there are drawn 
lines, paralel to the set frames. At the signal "now", the examinee moves as fast as possible from the first, starting line, runs, jumps over the first frame, goes through the second, jumps overr the third, goes through the fourth, entirely crosses the final line, turns around with $180^{\circ}$, runs, jumps over the fourth frame, goes through the third, jumps over the second, goes through the first and entirely crosses the beginning, starting line. The result of the test is the time of performance of the described motor task, expressed in the hundredths of a second.

\section{Deep forward bend on bench $(\mathrm{cm})$ :}

The examinee is standing barefoot in the position of joined heels, separated toes, on bench, with $60 \mathrm{~cm}$ tape measure fixed to its vertical side, with the starting side turned upwards and ending side towards the floor, $40 \mathrm{~cm}$ away from the board, where the examinee is standing. Bending forward, with the tips of toes and stretched out knees, the examinee tends to reach as low as possible, and thereby reaching the greater value on the scale of tape measure. The examinee has the right to try three times. The result is the depth of reach, expressed in centimeters.

Turn backwards with the bat $(\mathrm{cm})$ :

The examinee is standing with arms stretched out forward, and with such stretched arms, holding a bat, in the way that left hand is holding the handle and the right is next to the left. From the starting position, the examinee turns backwards, moving the bat behind the back. Left arm is fixed and the right one, if necessary, slides down the bat. The bat must not be dropped. Task needs to be performed three times without rest. The result is the distance between the inner edges of hands after the performed turn backwards, expressed in centimeters.

Leg backward from the lying on stomach position (degree):

The examinee is lying on stomach with the left side against the board with marked scale from 0 to 90 degrees. The upper border of pelvic bone is in line with the ordinate, hands are stretched forward, face turned towards the exercise mat. The examinee's task is to lift fully stretched out leg with the extension in foot as much as possible and holds it for a few moments in that position. The result is the degree to which the examinee managed to lift the leg.

Throwing a basketball ball from the sitting position on a chair $(\mathrm{cm})$ :

The examinee is sitting on a chair in front of which there is a marked line. $\mathrm{He} / \mathrm{she}$ is holding a basketball ball with both hands in the level of chest and throws it as far as possible with no body swing. The result is the distance, expressed in centimeters from the zero point, line, till the point of the first touch of the ball with the ground. 
$30 \mathrm{~m}$ running with the flying start (s):

The space for running should be as big to provide, apart from the marked $30 \mathrm{~m}$, enough space for taking a running start and running out (about 10-15 m from each side). On the athletic track a part of $30 \mathrm{~m}$ is measured. From the middle of that marked part, $10 \mathrm{~m}$ is measured vertically. The person who measures result is standing on that very point. At the beginning and ending of $30 \mathrm{~m}$ part of the track, from each side of the track, there are racks placed in the way that they cover the imagined line which goes from the eye of the measuring person and cut the side lines (start and finish) of the marked part of the track. When he/she wishes, the examinee starts from the place marked for the flying start. When the examinee cuts the imagined line between the racks next to the first line, the measuring person starts the stopwatch and stops in the moment when the examinee cuts the imagined line between the racks on the finish line. Each examinee has the right to try three times and the best result goes into the records. The result is the time during which the examinee runs the route of $30 \mathrm{~m}$, expressed in hundredths of a second.

\section{Pull-ups (s):}

The examinee is hanging in a pull-up position on shaft so that his/her chin is in line with the shaft bar. It is allowed for the examinee to come into the starting position with the help of the partner. The measuring person is standing on a chair so that his/her face is in line with the shaft bar, so that the examinee's position can be correctly monitored. As soom as the examinee's chin falls under the level of shaft bar, the measuring person stops the stopwatch. Test is performed only once. The result is expressed in full seconds from the moment when the examinee takes the required position to the moment when he/she is no longer able to stay in the named position.

\section{Torso lift-ups (number of repeats):}

The examinee is lying on the back, on the exercise mat, with bent legs in knees, under $90^{\circ}$ and with the feet apart, fixed with the assistance of the other examinee. The examinee's arms are bent in elbows, joined behind the head. At the signal "now", the examinee lifts and drops the torso as fast as possible within 15 seconds. The result is the total number of regularly performed torso liftings up to the vertical position within 15 seconds. Test is performed only once.

Metric characteristics of motor tests are measured on the same population in the following works (Momirović et al., 1969; Gredelj, Hošek, Viskić-Štalec, Horga, Metikoš, Marčelja, 1973; Stojanović, Momirović, Vukosavljević, Stolarić, 1975; Metikoš, Gredelj, Momirović, 1989).

Statistical analysis included the comparison of results for groups based on the class category. Using univariant analysis of variant, the difference among the age groups in all motor variables, separately for each gender, has been established. Using multivariant analysis of variant, the difference has been established in the 
Pavlović, S., Marinković, D., Mitrović, N.: Motor Skills of Primary School Children... ЗБОРНИК РАДОВА • ГОД. 23 • БР. 22 • ДЕЦЕМБАР 2020 • 181-194

parameters of motor skills on a general level among the age groups, separately according to gender. Both performed analyses have been performed on a statistical level of $\mathrm{p} \leq .05$ in SPSS 21.0 statistical package.

\section{THE RESULTS}

In the system of basic motor skills, the analysis of differences among the examinees of male gender of different age categories has showed that there are statistically significant differences among these groups in all variables $(\mathrm{F}=5.92 ; \mathrm{p}=$ $.00)$. The results of variant analysis show that boys are statistically significantly different in variables which estimate the speed of alternative movements (Hand tapping \& Hand clapping), explosive arm force (Throwing basketball ball), speed of running (30 m running), static arm force (Holding pull-ups) and repetitive strength from the hip joint (Torso lift-ups). Based on the arithmetic mean, it can be perceived that all differences are mostly in favour of older age. It is interesting to notice that the fifth grade examinees show worse results in tests of strength than the fourth grade examinees.

Table 1. Results of univariant (ANOVA) and multivariant (MANOVA) variant analysis on the sample of boys

\begin{tabular}{lcccccc}
\hline VARIABLE & $\begin{array}{c}\text { AM } \pm \text { SD } \\
\text { 3rd grade }\end{array}$ & $\begin{array}{c}\text { AM } \pm \text { SD } \\
\text { 4th grade }\end{array}$ & $\begin{array}{c}\text { AM } \pm \text { SD } \\
\text { th grade }\end{array}$ & $\begin{array}{c}\text { AM } \pm \text { 6D grade } \\
\text { th }\end{array}$ & f & p \\
\hline $\begin{array}{l}\text { Hand } \\
\text { tapping (no.r.) }\end{array}$ & $25.6 \pm 2.6$ & $23.7 \pm 2.65$ & $27.8 \pm 4.23$ & $25.1 \pm 3.92$ & 4.61 & .00 \\
$\begin{array}{l}\text { Leg } \\
\text { tapping (no.r.) }\end{array}$ & $18.8 \pm 2.4$ & $18.3 \pm 1.90$ & $20 \pm 2.12$ & $19.4 \pm 2.65$ & 1.16 & .32 \\
$\begin{array}{l}\text { Hand } \\
\text { clapping (no.r.) }\end{array}$ & $23.7 \pm 3.7$ & $25 \pm 3.10$ & $24 \pm 2.93$ & $23.5 \pm 2.75$ & 7.1 & .00 \\
$\begin{array}{l}\text { Backward } \\
\begin{array}{l}\text { Polygon (s) } \\
\text { Test of }\end{array}\end{array}$ & $14.6 \pm 3.0$ & $16.6 \pm 4.34$ & $15.6 \pm 2.20$ & $14.2 \pm 2.23$ & 1.51 & .21 \\
$\begin{array}{l}\text { coordination } \\
\text { Going through } \\
\text { and jumping ove } \\
\text { (no.r.) }\end{array}$ & $18.1 \pm 2.5$ & $19.2 \pm 3.14$ & $18.5 \pm 3.60$ & $17.5 \pm 2.81$ & 2.17 & .09 \\
$\begin{array}{l}\text { Deep forward } \\
\text { bend on bench } \\
\text { (cm) }\end{array}$ & $26 \pm 6.6$ & $27.3 \pm 5.03$ & $27 \pm 6.37$ & $27.9 \pm 7.48$ & .08 & .96 \\
$\begin{array}{l}\text { Baskwards turn } \\
\text { with the bat }\end{array}$ & $62.6 \pm 10.7$ & $67.3 \pm 12.82$ & $64.5 \pm 16.23$ & $67.9 \pm 9.62$ & .54 & .65 \\
$\begin{array}{l}\text { (degrees) } \\
\text { Leg backward }\end{array}$ & $99.6 \pm 14.8$ & $102 \pm 20.15$ & $102.4 \pm 13.61$ & $95.6 \pm 10.61$ & 1.64 & .18 \\
\hline
\end{tabular}


Pavlović, S., Marinković, D., Mitrović, N.: Motor Skills of Primary School Children... ЗБОРНИК РАДОВА • ГОД. 23 • БР. 22 • ДЕЦЕМБАР 2020 • 181-194

\begin{tabular}{|c|c|c|c|c|c|c|}
\hline $\begin{array}{l}\text { from lying } \\
\text { position (degre }\end{array}$ & & & & & & \\
\hline $\begin{array}{l}\text { Throwing } \\
\text { basketball } \\
\text { ball }(\mathrm{cm})\end{array}$ & $346.2 \pm 62.3$ & $409.1 \pm 82.1$ & $435 \pm 100.84$ & $514.9 \pm 85.6$ & 7.61 & .00 \\
\hline $\begin{array}{l}30 \mathrm{~m} \\
\text { running (s) }\end{array}$ & $5.8 \pm .5$ & $6.4 \pm .51$ & $5.4 \pm 0.41$ & $5.3 \pm .4$ & 11.48 & .00 \\
\hline Pull-ups (s) & $10.1 \pm 10.2$ & $10.8 \pm 14.99$ & $14.8 \pm 10.35$ & $43.3 \pm 22.1$ & 4.39 & .00 \\
\hline $\begin{array}{l}\text { Torso } \\
\text { lift-ups (no.r.) }\end{array}$ & $15.3 \pm 3.6$ & $13.2 \pm 3.63$ & $11.8 \pm 1.93$ & $14.7 \pm 4.3$ & 4.85 & .00 \\
\hline
\end{tabular}

Legend: AM - Arithmetic mean; SD - Standard deviation; $\mathrm{F}$ - value of $\mathrm{f}$ Test for MANOVA; P - Statistical significance for MANOVA; $\mathrm{f}$ - value of $\mathrm{f}$ test for ANOVA; $\mathrm{p}$ - statistical significance for ANOVA

In the system of basic motor skills, the analysis of difference among the examinees of female gender of different age categories, it showed that there are statistically significant differences $(F=4.79 ; p=.00)$ among these groups in the overall system of the analized variables. The analysis of variant shows that statistically significant differences appear only in a few variables. Those are variables which estimate the explosive arm force (Throwing basketball ball), speed of running (30 m running, flying start) and repetitive strength of hip joint (Torso lift-ups). Based on the arithmetic means it can be perceived these difference to be in favour of older age.

Table 2. Results of univariant (ANOVA) and multivariant (MANOVA) variant analysis on the sample of girls

\begin{tabular}{|c|c|c|c|c|c|c|}
\hline VARIABLE & $\begin{array}{l}\mathrm{AM} \pm \mathrm{SD} \\
\text { 3rd grade }\end{array}$ & $\begin{array}{l}\mathrm{AM} \pm \mathrm{SD} \\
4 \text { th grade }\end{array}$ & $\begin{array}{l}\mathrm{AM} \pm \mathrm{SD} \\
5 \text { th grade }\end{array}$ & $\begin{array}{l}\mathrm{AM} \pm \mathrm{SD} \\
\text { 6th grade }\end{array}$ & $\mathrm{f}$ & $\mathrm{p}$ \\
\hline $\begin{array}{l}\text { Hand } \\
\text { tapping (no.r.) }\end{array}$ & $23.5 \pm 3.9$ & $23.5 \pm 2.9$ & $26.2 \pm 4.8$ & $27.4 \pm 1.7$ & 1.03 & .38 \\
\hline $\begin{array}{l}\text { Leg } \\
\text { tapping (no.r.) }\end{array}$ & $18.4 \pm 2$ & $18.2 \pm 1.7$ & $19.6 \pm 3.9$ & $20.7 \pm 1.1$ & .51 & .67 \\
\hline $\begin{array}{l}\text { Hand } \\
\text { clapping (no.r.) }\end{array}$ & $22.8 \pm 2.5$ & $22.1 \pm 2.0$ & $22.4 \pm 1.4$ & $24.8 \pm 1.7$ & 1.14 & .33 \\
\hline $\begin{array}{l}\text { Backward } \\
\text { Polygon (s) }\end{array}$ & $14 \pm 2.4$ & $14.4 \pm 4.8$ & $14.1 \pm .7$ & $12.1 \pm 3.4$ & .49 & .69 \\
\hline $\begin{array}{l}\text { TesT of } \\
\text { coordination }\end{array}$ & $8.2 \pm 2$ & $8.35 \pm 3.7$ & $8.3 \pm 1.7$ & $7.7 \pm 5.4$ & .36 & .77 \\
\hline $\begin{array}{l}\text { Going through } \\
\text { and jumping } \\
\text { over (no.r.) }\end{array}$ & $15.1 \pm 3.6$ & $15.4 \pm 4.8$ & $15.2 \pm 1.4$ & $15 \pm 4.7$ & 1.38 & .25 \\
\hline Deep forward & $18.7 \pm 5.5$ & $19.4 \pm 6.6$ & $24 \pm .5$ & $21.5 \pm 5.8$ & 1.63 & .18 \\
\hline
\end{tabular}


Pavlović, S., Marinković, D., Mitrović, N.: Motor Skills of Primary School Children... ЗБОРНИК РАДОВА • ГОД. 23 • БР. 22 • ДЕЦЕМБАР 2020 • 181-194

\begin{tabular}{|c|c|c|c|c|c|c|}
\hline VARIABLE & $\begin{array}{l}\mathrm{AM} \pm \mathrm{SD} \\
3 \mathrm{rd} \text { grade }\end{array}$ & $\begin{array}{l}\mathrm{AM} \pm \mathrm{SD} \\
4 \text { th grade }\end{array}$ & $\begin{array}{l}\mathrm{AM} \pm \mathrm{SD} \\
5 \text { th grade }\end{array}$ & $\begin{array}{l}\mathrm{AM} \pm \mathrm{SD} \\
6 \text { th grade }\end{array}$ & $\mathrm{f}$ & $\mathrm{p}$ \\
\hline \multicolumn{7}{|l|}{$\begin{array}{l}\text { bend on bench } \\
(\mathrm{cm})\end{array}$} \\
\hline $\begin{array}{l}\text { Baskwards turn } \\
\text { with the bat } \\
\text { (degrees) }\end{array}$ & $72.1 \pm 13$ & $71.9 \pm 9.2$ & $74.9 \pm 0.6$ & $70.3 \pm 9.9$ & .28 & .83 \\
\hline $\begin{array}{l}\text { Leg backward } \\
\text { from } \\
\text { lying position } \\
\text { (degrees) }\end{array}$ & $90.4 \pm 13.8$ & $99.6 \pm 13.3$ & $94.6 \pm .2$ & $107 \pm 14.8$ & 2.06 & .11 \\
\hline $\begin{array}{l}\text { Throwing } \\
\text { basketball } \\
\text { ball }(\mathrm{cm})\end{array}$ & $427.6 \pm 56.2$ & $515 \pm 75.2$ & $550.4 \pm 6.7$ & $609 \pm 88.7$ & 6.28 & .00 \\
\hline $\begin{array}{l}30 \mathrm{~m} \\
\text { running (s) }\end{array}$ & $6.8 \pm .4$ & $6.4 \pm .5$ & $6.2 \pm 7.1$ & $5.9 \pm .7$ & 15.74 & .00 \\
\hline Pull-ups (s) & $16.4 \pm 8.2$ & $22.7 \pm 14$ & $19.1 \pm 1.6$ & $40.3 \pm 19.9$ & 1.49 & .22 \\
\hline $\begin{array}{l}\text { Torso } \\
\text { lift-ups (no.r.) }\end{array}$ & $13.2 \pm 2.4$ & $18.7 \pm 2.4$ & $12.7 \pm 4.7$ & $20.8 \pm 4.4$ & 20.02 & .00 \\
\hline & & & & & $=4.79$ & $P=.00$ \\
\hline
\end{tabular}

Legend: AM - Arithmetic mean; SD - Standard deviation; $\mathrm{F}$ - value of $\mathrm{f}$ теst for MANOVA; $\mathrm{P}$ - Statistical significance for MANOVA; $\mathrm{f}$ - value of $\mathrm{f}$ test for ANOVA; $\mathrm{p}$ - statistical significance for ANOVA

\section{DISCUSSION}

The purpose of this research was to analyse the differences in motor skills of primary school children age 10-13. Presented results point to the existaning differences among the groups of examinees of both genders on a general level, as well as individual differences within motor space. These differences are more expressed among boys $(\mathrm{F}=5.92 ; \mathrm{P}=.00)$, then among girls $(\mathrm{F}=4.79 ; \mathrm{P}=.00)$. Based on the conducted research on the sample of 213 students of both gender, it can be concluded that the sixth grade students of both genders were mostly more successful in performing motor tests. Statistically significant difference has been perceived among boys in the following variables: "Hand tapping", "Hand clapping", "Throwing basketball ball", "30 m running flying start", "Pull-ups" and "Torso liftups". Among girls there were some statistically significant differences in the following variables: "Throwing basketball ball", "30m running flying start" and "Torso lift-ups".

Such results can be a consequence of the morphologic characteristics of older examinees. To be more precise, the older the examinees were, the greater their running speed was, that is, they were faster, probably thanks to the morphologic 
charactersitics and the fact that long bars provide, without greater share of compensation movement, mastering of the available space, which can all be the consequene of the development of lower extremities and greater extremity lengths which provided the achievement of bigger step length and then decrease of step frequency when running a certain route (Kerić \& Ujsasi, 2014). One of the features of this research is the absence of differences in speed among girls, when it comes to upper extremities.

Manifestation of differences in strength with examinees of both genders is mostly in favour of the higher grades. This fact does not represent any surprise, since the adolescent factor which implies the increase of muscle mass, especially with boys, is more dominant at an older primary school age. In addition to that, there are the results after testing the explosive and repetitive strength, as well as the static force of arms. The development of strength depends on the skeleton mass, potential volume of muscles (the quantity of muscle fibres - myofibrils), muscle viscosity, CNS functioning, and mostly on the way of exercising and diet (Smajić et al., 2017). Regardless of the significat level of the inborn strength, with certain physical exercasing, it can be immensely influenced on its development (Jovanović, 2007), so we can say that with older age categories of the examinees, exactly that fact of development has significantly stood out.

The value of this work is reflected in the fact that during the testing, a great number of tests for evaluation of the examinees' motor space have been used, all for the purpose of getting more thorough image on the existing differences among the groups. In the character of such setting, with significant number of tests, in certain dimensions there have been no differences among the groups of examinees. We can tell that the difference was expected in the tests for evaluation of coordination and flexibility, but such results have not been achieved. One of the possible reasons for that can be a mere fact that in the pre-adolescent and adolescent period, there comes to a longitude growth of skeleton and extremities, which brings to the change of level of coordination abilities. However, such created coordination conditions are not enough because the kineasthetic feeling has not been enough developed. Therefore, the results of older grades examinees have not been far better than the ones of younger examinees. In coordinatively more complex movements, there has been a clear synergic economy of moves, motor reactions have been slow and not precise and such results were the same in some previous researches (Smajić et al., 2017).

Apart from that fact that the motor space of children has been, to a great degree, a matter of research and evaluation, the value of this work lies in the fact that a wider composition of tests has been applied, as well as some tests which did not earlier estimate the motor status of children. It has to be pointed out that this work is just a part of one more extensive research and project which includes the testing of preciseness, endurance and balance. However, considering the current situation related to the appearance of COVID-19 virus, it was not possible to 
organize such testing. The contribution to completing the overall structure of motor space of children can be exactly conducting all those tests and as such, developing and putting them at the diposal of teachers and professors, in order to evaluate their work with the highest quality.

\section{CONCLUSION}

According to curriculum, it is necessary to test motor skills of students every school year. Differences are perceived both among the examinees of the same gender and among the examinees of different age (grade). The importance of testing and perceiving differences in motor skills and their monitoring represents one of the important activities during classes of Physical Education, all of it for the purpose of adequate lesson planning, but also for the sake of motor development monitoring (Pavlović, 2017). Physical Education classes are the only ones where the improvement of children's motor development as a part of overall quality health condition can be adequately and reliably estimated. 


\section{References}

Bala, G., Kiš, M. i Popović, B. (1996). Trening u razvoju motoričkog ponašanja male dece. Godišnjak Fakulteta fizičke kulture, 8, 83-87.

Buišić, S., Cvejić, D., Vuković Živković, A. \& Pejović, T. (2013). Quantitative differences in motor abilities and basic anthropometrics characteristics of boys and girls from fourth grade of primary school. Glasnik Antropološkog društva Srbije, $48,121-127$.

Clark, J. E. \& Metcalf, J. S. (2002). The mountain of motor development: A metaphor. In J. E. Clark \& J. H. Humphrey (eds.): Motor development: Research and reviews, volume 2 (163-190). Reston, VA: National Associotion for Sport and Physical Education.

Drabik, J. (1996). Children \& Sports Training. Stadion Publishing Company, Inc. Island Pond, Vt.

Gredelj, M., Hošek, A., Viskić-Štalec, N. Horga, S., Metikoš, D. i Marčelja, D. (1973). Metrijske karakteristike testova namijenjenih za procjenu faktora reorganizacije stereotipa gibanja. Kineziologija, 3(2), 29-37.

Horvat, T. i Vuleta, D. (2002). Razlike u nekim motoričkim sposobnostima između učenika 5-8. razreda O.ŠS. „Josipa Račića” i učenika 5-8 razreda u OŠ u Hrvatskoj. U V. Findak (ur.). Zbornik radova 11. ljetne škole kineziologa Republike Hrvatske Programiranje rada u području edukacije, sporta, sportske rekreacije i kineziterapije. Zagreb: Hrvatski kineziološki savez.

Katić, R., Miletić, D., Maleš, B., Grgantov, Z. i Krstulović, S. (2005). Antropološki skolopovi sportaša. Split: Fakultet PM ZK.

Kerić, M. i Ujsasi, D. (2014). Kvantitativne razlike u motoričkim sposobnostima učenika viših razreda osnovne škole. TIMS Acta, 8, 23-30.

Malina, R. M., Koziel, S. \& Bielicki, T. (1999). Variation in subcutaneous adipose tissue distribution associated with age, sex and maturation. American Journal of Human Biology, 11, 89-100.

Matić, M. (1978). Čas telesnog vaspitanja. Beograd: NIP Partizan.

Metikoš, D., Gredelj, M. i Momirović, K. (1979). Struktura motoričkih sposobnosti. Kineziologija, 9(1-2), 25-50.

Momirović, K. i sar. (1969). Uticaj latentnih antropometrijskih varijabli na orijentaciju $i$ selekciju vrhunskih sportaša. Zagreb: PE College.

Nićin, D. (2000). Antropomotorika. Novi Sad: Fakultet fizičke kulture.

Pavlović, S. (2017). Prediktori fizičke aktivnosti učenika na času fizičkog vaspitanja. (Doktorska disertacija). Novi Sad: Fakultet fizičke kulture. 
Pavlović, S., Marinković, D., Mitrović, N.: Motor Skills of Primary School Children... ЗБОРНИК РАДОВА • ГОД. 23 • БР. 22 • ДЕЦЕМБАР 2020 • 181-194

Privitellio, S., Jogunica, R., Gulan, G. i Boschi, V. (2007). Utjecaj sportskog programa na promjene motoričkih sposobnosti predškolaca. Medicina, 43, 204-209.

Sabolč, H. i Lepeš, J. (2012). Razlike u motoričkim sposobnostima i telesnoj kompoziciji između dečaka i devojčica od 7 godina. Sportske nauke i zdravlje, 2(1), 75-79.

Smajić, M., Marinković, A., Đorđić, V., Čokorilo, N., Gušić, M. i Štajer, V. (2017). Razlike u morfološkim karakteristikama i motoričkim sposobnostima devojčica i dečaka mlađeg školskog uzrasta. Glasnik Antropološkog društva Srbije, 52, 83-93.

Stojanović, M., Momirović, K., Vukosavljević, R. i Stolarić, S. (1975). Struktura antropometrijskih dimenzija. Kineziologija, 5(1-2), 193-205. 
Pavlović, S., Marinković, D., Mitrović, N.: Motor Skills of Primary School Children... ЗБОРНИК РАДОВА • ГОД. 23 • БР. 22 • ДЕЦЕМБАР 2020 • 181-194

\section{Слободан Љ. Павловић}

Универзитет у Крагујевцу, Педагошки факултет у Ужицу

Драган Б. Маринковић

Универзитет у Новом Саду, Факултет спорта и физичког васпитања

Небојша 3. Митровић

Универзитет Бијељина, Педагошки факултет

\section{МОТОРИЧКЕ СПОСОБНОСТИ ДЕЦЕ ОСНОВНОШКОЛСКОГ УЗРАСТА - РАЗЛИКЕ У ОДНОСУ НА УЗРАСТ}

\section{Резиме}

Физичко образовање од најранијег узраста у предшколским установама, преко основних и средњих школа је једино место где деца могу направи начин да у своје спортска знања, вештине, понашање што је неопходно како би наставили континуитет физичкеа ктивностии у одраслом добу. Време у основној школи је период када се код ученика догађају велике промене у целокупном развојном статусу, тестога физичко васпитање има фундаменталну улогу за развој свих психосоматских карактеристика деце. Приликом конципирања часова физичког васпитања посебан акценат се ставља на развој моторичких способности. Циљ овог истраживачког рада, се односи на утврђивање постојања разлика у моторичком простору деце основношколског узраста у односу на узраст. Узорак је сачињавао 231 испитаник који су похађали 3., 4., 5., и 6. разред (старости $11 \pm 1,6$ година) од којих је дечака ( $\mathrm{N}=109 ; \mathrm{TV}=147,6 \pm 7 ; \mathrm{TM}=39,6 \pm 7,1)$ девојчица (N $=122 ; \mathrm{TV}=148,3 \pm 5,9 ; \mathrm{TM}=40 \pm 5,3)$. Сви испитаници су бил и ученици са територије златиборског округа и са потписаном дозволом за обављање тестирања од стране оба родитеља. Моторичке способности процењиване су моторичким тестовима који су значајно обухватнији од досада примењиваних у школском физичком васпитању, а све у циљу добијања реалније слике о процени моторичког простора деце. Приказани резултати указују на постојање разлика између група испитаника код оба пола на генералном нивоу, као и на појединачне разлике унутар моторичког простора. Ове разлике су више изражене код дечака $(\mathrm{F}=5,92$; $\mathrm{P}=0,00)$ него код девојчица $(\mathrm{F}=4,79 ; \mathrm{P}=0,00)$. Статистички значајна разлика код дечака је констатована у варијаблама „Тапинг руком”, „Пљесак рукама”, „Бацање кошаркашке лопте”, „Трчање на 30 м летећи старт”, „Вис у згибу” и „Подизање трупа”. Код девојчица статистички значајне разлике су испољене у варијаблама „Бацање кошаркашке лопте”, „Трчање на 30 м летећи старт” и „Подизање трупа”. Вредност овог рада се огледа и у томе што је током тестирања коришћен велики број тестова за процену моторичког простора испитаника, а све са циљем како би се дошло до комплетније слике о постојању разлика између група подељених по полу и узрасту. Важност тестирања и уочавања разлика у моторичким способностима и њихово праћење представља једну од важнијих активности током наставе физичког васпитања, а све у циљу адекватног програмирања наставе, али и праћења моторичког развоја.

Кључне речи: моторички развој, физичко образовање, моторички nростор, nраћење. 